\title{
How Strong is the Linkage between Tourism and Economic Growth in Europe?
}

\author{
Nikolaos Antonakakis ${ }^{* \dagger} \quad$ Mina Dragouni ${ }^{\ddagger} \quad$ George Filis $^{\S}$ \\ November 18, 2014
}

\begin{abstract}
In this study, we examine the dynamic relationship between tourism growth and economic growth, using a newly introduced spillover index approach. Based on monthly data for 10 European countries over the period 1995-2012, our analysis reveals the following empirical regularities. First, the tourism-economic growth relationship is not stable over time in terms of both magnitude and direction, indicating that the tourism-led economic growth (TLEG) and the economic-driven tourism growth (EDTG) hypotheses are time-dependent. Second, the aforementioned relationship is also highly economic event-dependent, as it is influenced by the Great Recession of 2007 and the ongoing Eurozone debt crisis that began in 2010. Finally, the impact of these economic events is more pronounced in Cyprus, Greece, Portugal and Spain, which are the European countries that have witnessed the greatest economic downturn since 2009. Plausible explanations of these results are provided and policy implications are drawn.
\end{abstract}

Keywords: Tourism-led economic growth, Economic-driven tourism growth, Spillover, Time-varying relationship, Variance decomposition, Europe

JEL codes: C32, F43, L83, O52

\footnotetext{
* Corresponding author. Vienna University of Economics and Business, Department of Economics, Institute for International Economics, Welthandelsplatz 1, 1020, Vienna, Austria. E-mail: nikolaos.antonakakis@wu.ac.at, phone: +43/1/313 36-4141, fax: +43/1/313 36-90-4141.

${ }^{\dagger}$ University of Portsmouth, Economics and Finance Subject Group, Portsmouth Business School, Portland Street, Portsmouth, PO1 3DE, United Kingdom. E-mail: nikolaos.antonakakis@port.ac.uk

$\ddagger$ University College London (UCL), Institute for Sustainable Heritage, The Bartlett, UCL Faculty of the Built Environment, Central House, 14 Upper Woburn Place, WC1H 0NN, London, UK

$\S$ Bournemouth University, Department of Accounting, Finance and Economics, Executive Business Centre, 89 Holdenhurst Road, BH8 8EB, Bournemouth, UK
} 


\section{Introduction}

Europe is considered as a prominent tourist destination, holding approximately a $40 \%$ share of the global tourist arrivals in 2011 (European Commission, 2012). For this reason, the European Union (EU) has placed much emphasis on the tourism sector as an engine of economic prosperity for its member countries (Lee and Brahmasrene, 2013), given that the tourism sector does not merely represent a significant revenue stream, but also a vital source of employment and entrepreneurial vitality. In a global scale, the tourism industry accounts for $5 \%$ of the world GDP and almost 30\% of world exports of services (UNWTO, 2012a). Furthermore, tourism development has been established as a popular strategy for economic growth not only in Europe but worldwide (Matarrita-Cascante, 2010; Andereck et al., 2005), thus a lot of interest and research has been generated on the link between tourism growth and economic growth.

Yet, there is still no consensus on both theoretical and empirical grounds on whether tourism promotes economic activity, or economic activity leads to tourism growth. This could be due to the fact changes in economic and/or tourism conditions can alter the nature and magnitude of the relationship between these two series over time, among others. Nonetheless, its examination in a time-varying framework has been largely ignored in the literature. On top of that, and in light of the recent economic developments of 200708 global financial crisis and its subsequent European debt crisis, it is thus warranted to examine whether and how these incidents have affected the relationship between tourism and economic growth. The determination and the extent of the aforementioned timevarying relationship is valuable for informing current and future EU and national policy frameworks (Chen and Chiou-Wei, 2009). Therefore, the aim of this paper is to investigate the link between tourism growth and economic growth, by paying particular attention to its time-varying nature and its relation to the global financial and European debt crisis.

From a theoretical perspective, Lanza and Pigliaru (2000) were among the first to investigate the link between tourism and economic growth. Based on their observations that countries with relatively large tourism sectors exhibit higher than average economic growth, they developed a Lucas-type two-sector model. In this model, production in one of the sectors (called tourism) which depends on endowments of a natural resource, and showed that countries with relative abundant natural resources will specialize in tourism and achieve a faster rate of economic growth.

On empirical grounds, studies seeking to determine the link between tourism and economic growth, have established four empirical regularities that can be translated into the following four main hypotheses (Chatziantoniou et al., 2013). The first two hypotheses postulate a unidirectional causality between the two variables, either from tourism to economic growth (tourism-led economic growth hypothesis - TLEG) or its reverse (economicdriven tourism growth hypothesis - EDTG). The third and forth hypotheses support the existence of a bidirectional relationship between tourism and the economy (bidirectional causality hypothesis - BC) or that there is no relationship at all (no causality hypothesis - NC), respectively.

According to the TLEG hypothesis, there is a flow of benefits from tourism to the economy, which spillover through multiple routes (Schubert et al., 2011). In particular, it is believed that tourism (i) increases foreign exchange earnings, which in turn can be used to finance imports (McKinnon, 1964), (ii) it encourages investment and drives local 
firms towards greater efficiency due to the increased competition (Krueger, 1980; Balaguer and Cantavella-Jorda, 2002), (iii) it alleviates unemployment, since tourism activities are heavily based on human capital (Brida and Pulina, 2010) and (iv) it leads to positive economies of scale thus, decreasing production costs for local businesses (Andriotis, 2002; Croes, 2006). Other recent studies which find evidence in favour of the TLEG hypothesis include Sugiyarto et al. (2003), Durbarry (2004), Parrilla et al. (2007), Croes and Vanegas (2008), Proenca and Soukiazis (2008), Fayissa et al. (2011), Pratt (2011), Dritsakis (2012), Eeckels et al. (2012), Ivanov and Webster (2013), Surugiu and Surugiu (2013).

Even though much of the recent evidence is in favour of the TLEG, there is a strand of the literature that paints the opposite picture, i.e. that it is the tourism sector which is affected by economic fluctuations (Narayan, 2004; Oh, 2005; Payne and Mervar, 2010; Tang, 2011). As Payne and Mervar (2010) explain, the EDTG hypothesis maintains that the tourism growth of a country is mobilised by the application of well-designed economic policies, governance structures and investments in both physical and human capital. These create a positive economic climate that encourages tourism activities to proliferate and flourish, given the availability of resources, infrastructure and political stability.

Pertaining to the readily available information, bidirectional causality could also exist between tourism income and economic growth (see, inter alia, Lee and Chang, 2008; Chen and Chiou-Wei, 2009; Seetanah, 2011; Apergis and Payne, 2012; Ridderstaat et al., 2013). From a policy view, a reciprocal tourism-economic growth relationship implies that government agendas should cater for promoting both areas simultaneously. Finally, there are some studies that do not offer support to any of the aforementioned hypotheses, suggesting that the impact between tourism and economic growth is insignificant (Po and Huang, 2008; Katircioglu, 2009; Tang and Jang, 2009).

To provide a synopsis, the tourism-economic growth relationship has been the subject of considerable study and debate. The current empirical work, along with its diversified results, illuminates that there is not a generally applicable hypothesis which can be a priori accepted as axiomatic. More importantly, the examination of the said relationship in a dynamic setup has been largely ignored, given that the aforementioned studies are conducted on a static environment. It is only recently that Lean and Tang (2010), Arslanturk et al. (2011) and Tang and Tan (2013) challenged the stability of the tourism-economic growth relationship, showing that it changes over time.

More specifically, Tang and Tan (2013) use rolling sub-sample TYDL Granger causality analysis (Toda and Yamamoto, 1995; Dolado and Lutkepohl, 1996) with monthly data of industrial production and international tourist arrivals from January 1989 to February 2009 for Malaysia. Although their findings support the TLEG hypothesis, they show that the tourism-growth link changes over time by becoming either more or less pronounced. Arslanturk et al. (2011), using a rolling-window Vector Error Correction Model, show that the impact of tourism receipts on Turkish GDP is negative until 1983 and turns into a positive effect in the post-1983 period. Tang and Tan (2013) also focus on Malaysia, using a recursive Granger-causality test to study the time-varying relationship between international tourist arrivals and industrial production. Their results reveal that the positive effect of tourism on economic growth is not stable over time. Nevertheless, their studies focus solely on Turkey and Malaysia. 
In this light, there is scope for extending this strand of the literature to other regions and countries. The purpose of this study is to investigate the relationship between tourism and economic growth in a time-varying environment, focusing on Europe for the period 1995-2012. To that end, we employ the novel measure of a VAR-based spillover index, developed by Diebold and Yilmaz (2012), to evaluate the link between the two factors. The choice of a VAR model is justified by the fact that such models help to alleviate the endogeneity problem observed in the tourism-economic growth relationship by treating all variables as potentially endogenous and explicitly modelling the feedback effects across them. The VAR-based spillover index has already attracted a considerable attention in the economic literature (see, inter alia, McMillan and Speight, 2010; Yilmaz, 2010; Bubák et al., 2011; Antonakakis, 2012; Zhou et al., 2012; Antonakakis and Badinger, 2014) and this is its first application to the tourism context.

Our findings suggest that: first, the tourism-economic growth relationship is not stable over time in terms of both magnitude and direction, indicating that the tourism-led economic growth (TLEG) and the economic-driven tourism growth (EDTG) hypotheses are time-dependent. This is the main contribution of this study, as previous studies on the time-varying fluctuations concern only the magnitude of this relationship and not its direction (see, for instance, Lean and Tang, 2010; Arslanturk et al., 2011; Tang and Tan, 2013). Second, the aforementioned relationship is also extremely economic eventdependent, as it is influenced by the Great Recession of 2007 and the ongoing Eurozone debt crisis that begun in 2010. Finally, the impact of these economic events is more pronounced on Cyprus, Greece, Portugal and Spain, which are the European countries that have witnessed the greatest economic downturn since 2009 and their tourism sector plays a prominent part in their economies.

The rest of the paper is organised as follows. Section 2 describes the methodology and the data sets used. Section 3 presents the empirical results and Section 4 draws the conclusions of the study along with the policy implications.

\section{Methodology and data description}

\section{$2.1 \quad$ Empirical methodology}

This study employs the spillover index by Diebold and Yilmaz (2012), which generalises the original index, first developed by Diebold and Yilmaz (2012). Spillovers allow for the identification of the inter-linkages between the variables of interest. Diebold and Yilmaz (2009) framework allows the estimation of the total spillover index, whereas DDiebold and Yilmaz (2012) extend the work of Diebold and Yilmaz (2009) in two respects.

First, they provide refined measures of directional spillovers and net spillovers, providing an 'input-output' decomposition of total spillovers into those coming from (or to) a particular source/variable and allowing the identification of the main recipients and transmitters of shocks. Second, in line with Koop et al. (1996) and Pesaran and Shin (1998), a generalized vector autoregressive framework in used by Diebold and Yilmaz (2012), where forecast-error variance decompositions are invariant to the ordering of the variables (in contrast to Cholesky-factor identification used in Diebold and Yilmaz, 2012). In the context of the present study, this is particularly important since it is hard, if not impossible, 
to justify one particular ordering of the tourism and economic growth variables, given the fact that there are four distinct hypotheses dealing with their relationship.

Following Diebold and Yilmaz (2012), we estimate a VAR model, which takes the following general form (for a detailed description of the VAR model, see Lutkepohl, 2006):

$$
\mathbf{y}_{t}=\sum_{i=1}^{q} \mathbf{B}_{i} y_{t-1}+\varepsilon_{t}
$$

where $y_{t}$ is $N \times 1$ vector of endogenous variables, $\mathbf{B}_{i}$ are $N \times N$ are autoregressive coefficient matrices and $\varepsilon_{t}$ is a vector of error terms that are assumed to be serially uncorrelated. The VAR model for each country contains two variables $(N=2)$, namely the international tourist arrivals growth rates and industrial production growth rates. Key to the dynamics of the system is the moving average representation of Equation (1) which is written as $\mathbf{y}_{t}=\sum_{j=1}^{\infty} \mathbf{A}_{j} \varepsilon_{t}$, where the $N \times N$ coefficient matrices $\mathbf{A}_{j}$ obey the recursion of form $\mathbf{A}_{j}=$ $B_{1} \mathbf{A}_{j-1}+B_{2} \mathbf{A}_{j-2}+\ldots+B_{p} \mathbf{A}_{j-p}$, with $\mathbf{A}_{0}$ being the $N \times N$ identity matrix and $\mathbf{A}_{j}=0$ for $j<0$. The total, directional and net growth rate spillovers are produced by the generalised forecast-error variance decompositions of the moving average representation of the VAR model in Equation (1). The advantage of the generalised variance decomposition is that it eliminates any possible dependence of the results on the ordering of the variables. Pesaran and Shin (1998) define the H-step-ahead generalised forecast-error variance decomposition as:

$$
\theta_{i j}(H)=\frac{\sigma_{j j}^{-1} \sum_{h=0}^{H-1}\left(e_{i}^{\prime} A_{h} \Sigma e_{j}\right)^{2}}{\sum_{h=0}^{H-1}\left(e_{i}^{\prime} A_{h} \Sigma A_{h}^{\prime} e_{i}\right)}
$$

where $\Sigma$ denotes the variance matrix of the error vector $\varepsilon, \sigma_{j j}$ denotes the error term's standard deviation for the $j$-th equation and $e_{i}$ a selection vector with one as the $i$-th element and zeros otherwise. This yields a $N \times N$ matrix $\theta(H)=\left[\theta_{i j}(H)\right]_{i, j=1,2}$, where each entry gives the contribution of variable $j$ to the forecast error variance of variable $i$. The own-variable and cross-variable contributions are contained in the main diagonal and the off-diagonal elements of $\theta(H)$ matrix, respectively.

Since the own and cross-variable variance contribution shares do not sum to one under the generalized decomposition, i.e., $\sum_{j=1}^{N} \theta_{i j}(H) \neq 1$, each entry of the variance decomposition matrix is normalized by its row sum, as follows:

$$
\tilde{\theta}_{i j}(H)=\frac{\theta_{i j}(H)}{\sum_{j=1}^{N} \theta_{i j}(H)}
$$

with $\sum_{j=1}^{N} \tilde{\theta}_{i j}(H)=1$ and $\sum_{i, j=1}^{N} \tilde{\theta}_{i j}(H)=N$ by construction.

This ultimately allows to define a total growth spillover index, as:

$$
T S(H)=\frac{\sum_{i, j=1, i \neq j}^{N} \tilde{\theta}_{i j}(H)}{\sum_{i, j=1}^{N} \tilde{\theta}_{i j}(H)} \times 100=\frac{\sum_{i, j=1, i \neq j}^{N} \tilde{\theta}_{i j}(H)}{N} \times 100
$$

which gives the average contribution of spillovers from shocks to all (other) variables to the total forecast error variance.

Moreover, this approach is quite flexible and allows to obtain a more differentiated picture by considering directional spillovers: Specifically, the directional spillovers received 
by variable $i$ from all other variables $j$ are defined as

$$
D S_{i \leftarrow j}(H)=\frac{\sum_{j=1, j \neq i}^{N} \tilde{\theta}_{i j}(H)}{\sum_{i, j=1}^{N} \tilde{\theta}_{i j}(H)} \times 100=\frac{\sum_{j=1, j \neq i}^{N} \tilde{\theta}_{i j}(H)}{N} \times 100
$$

and the directional spillovers transmitted by variable $i$ to all other variables $j$ as

$$
D S_{i \rightarrow j}(H)=\frac{\sum_{j=1, j \neq i}^{N} \tilde{\theta}_{j i}(H)}{\sum_{i, j=1}^{N} \tilde{\theta}_{j i}(H)} \times 100=\frac{\sum_{j=1, j \neq i}^{N} \tilde{\theta}_{j i}(H)}{N} \times 100 .
$$

Notice that the set of directional spillovers provides a decomposition of total spillovers into those coming from (or to) a particular source. For instance, in the present application this means that our spillover matrix $\theta(H)$ consists of the main diagonal elements reflecting tourism growth-to-tourism growth and economic growth-to-economic growth spillovers, and the off-diagonal elements reflecting tourism growth-to-economic growth and economic growth-to-tourism growth spillovers.

Finally, subtracting Equation (6) from Equation (5), we can obtain the net spillovers from tourism growth (economic growth) to economic growth (tourism growth) as:

$$
N S_{i}(H)=D S_{i \rightarrow j}(H)-D S_{i \leftarrow j}(H) .
$$

The spillover index approach provides measures of the intensity of interdependence across tourism growth and economic growth and allows a decomposition of spillover effects by source and recipient. As such, the directional spillovers distinguish the proportion of the total spillovers from tourism (economic) to economic (tourism) growth. Finally, the net spillovers indicate which of the two variables (either tourism growth or economic growth) is a transmitter of spillovers in net terms. For instance, if tourism (economic) growth is the net transmitter of spillovers, then the TLEG (EDTG) hypothesis holds.

\subsection{Data}

We use monthly data of ten European countries, retrieved from Eurostat database, covering different time spans between 1995 and 2012. The choice of the specific time period and countries is purely based on data availability and is given in Table 1 . It is worth noting that our sample countries include both economies that have been heavily affected by the Great Recession of 2007 and the ongoing Eurozone debt crisis, namely, Cyprus, Greece, Italy, Portugal and Spain, as well as, countries with stronger economies, namely, Austria, Germany, Netherlands, Sweden and the United Kingdom. Thus, despite the fact that data availability issues force us to exclude some additional countries, our study still embraces destinations with varied tourism activity and economic performance, forming a sufficiently representative sample.

\section{[Insert Table 1 around here]}

The variables taken into consideration are industrial production, as a proxy of economic growth (similar to Bjørnland and Leitemo, 2009; Laopodis, 2009; Espinoza et al., 2012; Peersman and Van Robays, 2012, among others) and the number of international 
tourist arrivals serving as a proxy of tourism performance (as in Narayan, 2004; Tang, 2011; Dritsakis, 2012; Tang and Tan, 2013). The industrial production series are already seasonally adjusted, while the international tourist arrivals series are not. Therefore, we seasonally adjust the international tourist arrivals series based on the Census X-12ARIMA procedure so as to remove seasonal pattern that would potentially distort our results. The seasonally adjusted versions of these two series are presented in Figure 1.

\section{[Insert Figure 1 around here]}

In panels $\mathrm{A}$ and $\mathrm{B}$ of Table 2 we report the descriptive statistics of the seasonally adjusted series of industrial production and international tourism arrivals.

\section{[Insert Table 2 around here]}

As our VAR analysis below evolves around the short-run dynamics of the linkage between tourism and economic growth, the series in the VAR model ought to be stationary. ${ }^{1}$ We thus perform several unit root tests for robustness purposes. In particular, we employ the Augmented Dickey-Fuller (ADF) test based on Dickey and Fuller (1979), the modified Dickey-Fuller $t$ (DF-GLS) test of Elliott et al. (1996), the $\mathrm{Ng}$ and Perron (NP) test of Perron and Ng (1996), and the Lee-Strazicich (LS) test of Lee and Strazicich (2003). The choice of these tests is based on the following criteria. First, the ADF is a classical and most frequently unit root test used in empirical analyses. Second, we also use the DF-GLS and the NP unit root tests, as these tests have significantly greater power than the ADF. Finally, unlike the other three tests, the LS unit root test allows for the possibility of endogenous break(s) in the series that may curtail the power of classical unit root tests. ${ }^{2}$ The LS test has two distinctive features. First, by allowing for a structural break under both the null and alternative hypotheses, it addresses the problem of size distortion, inherent in other unit root tests. Second, it allows for more than one break in the series. ${ }^{3}$ More generally, in a longer time series, the likelihood of breaks is naturally higher and thus the choice of a more general unit root test is warranted. ${ }^{4}$

Panels A and B of Table 2 provide firm evidence that the seasonally adjusted series in levels have a unit root. Thus, the unit root tests endorse the use of variables in first differences in our empirical models. In particular, we transform the seasonally adjusted series of industrial production and international tourist arrivals into growth rates by taking the first difference of the natural logarithms of seasonally adjusted industrial production and seasonally adjusted international tourist arrivals, respectively. In general, all unit

\footnotetext{
${ }^{1}$ In the present study, we do not account for cointegration between industrial production and international tourist arrivals, as it is not the main scope of this paper. We, however, leave this cointegration analysis for potential future research.

${ }^{2}$ Indeed, in the presence of a break in the series, the classical unit root tests will diagnose the series as difference-stationary, although before and after the break the series are actually trend-stationary. Thus, if the presence of a break in the series is neglected, misleading inference may ensue.

${ }^{3}$ In our test equations, we assume two structural breaks for the LS tets. Assuming one break though, led to similar conclusions.

${ }^{4}$ Moreover, we have also distinguished between two cases in terms of the presence of deterministic components in the test equation, a test equation with a constant, and a test equation with a constant and a linear trend. As both cases led to similar conclusions, we present one of the case, namely the one with a constant in the test equation.
} 
root tests in Panels $\mathrm{C}$ and $\mathrm{D}$ of Table 2 affirm that the economic growth and tourism growth series are stationary.

As evident from Table 2, industrial production (Panel A) exhibits a lower volatility compared to the tourism series (Panel B). In addition, we observe that apart from Cyprus, the changes in tourist arrivals are positive for all other countries. On the other hand, five out of ten countries experience, on average, a negative growth in their industrial production. These countries include Cyprus, Greece, Italy, Portugal and the UK. This is not a surprising result considering that these regions suffered a significant decline in their economic performance, especially during the latter part of the sample period. All series are stationary based on the ADF test. Finally, none of the series are normally distributed, as indicated by the skewness, kurtosis and Jarque-Bera statistics. The evolution of the series growth rates over the sample period is depicted in Figure 2.

\section{[Insert Figure 2 around here]}

It is clear from this graph, that both series experience substantial declines during recessions.

\section{Empirical findings}

\subsection{Spillover indices}

We begin our analysis with the examination of the VAR-based model estimates in order to provide some preliminary evidence on the relationship between international tourist arrivals and economic growth in the countries under investigation. Since the focus of this paper is on the spillover effects and for the sake of brevity, the actual VAR estimates, along with their impulse response functions, as well as, the Granger-causality tests are not reported here but they are available upon request. Figure 3 presents a summary of the causality direction between our series for each country.

[Insert Figure 3 around here]

Figure 3 suggests that different countries provide support to a different hypothesis. The TLEG hypothesis is evident only for Italy and the Netherlands, while the EDTG is observed in Cyprus, Germany and Greece. Furthermore, there is evidence of bidirectional causality in the cases of Austria, Portugal and Spain, while no causality can be identified for Sweden and the UK. Given that we do not find any causality in the cases of Sweden and the UK, these countries are excluded from the remaining analysis.

The next step, is to examine the total growth spillover table, by first presenting its generic form in Table 3. The rows in Table 3 (contributions FROM others) report the contribution to the forecast error variance of series $i$ and $j$, stemming from innovations to series $j$ and $i$, where $i, j$ are the industrial production and international tourist arrivals growth, respectively. The reverse contribution is illustrated in the columns of Table 3 (contributions TO others). The table also exhibits the total contribution of each series, including own contributions. The difference between the contributions $T O$ others and contributions FROM others provides the net growth rate spillovers. A positive figure 
suggests that a particular series is a net transmitter of shocks, whereas a negative figure denotes that the series is a net receiver. Finally, Table 3 also reports the total growth spillover index, which is the sum of the contributions FROM or TO others relative to the sum of the total contributions including own. Thus, the total growth spillover index indicates the average effect on both series across the whole sample.

\section{[Insert Table 3 around here]}

Table 4 presents the total spillover index results based on the study of Diebold and Yilmaz (2012) for the countries in our sample.

\section{[Insert Table 4 around here]}

The total spillover indices reveal a quite low average effect. The only exceptions are Austria and Portugal which exhibit a slightly higher level of total spillovers. The lowest score is reported for Cyprus. This result is somewhat unexpected as Cyrpus is considered a country with a tourism sector of substantial size relative to its aggregate economy. Overall, the total spillover indices illustrate that, on average, there is a weak to moderate interdependence between tourism and economic growth for most countries.

The net spillovers for the whole sample demonstrate that tourism is the transmitter of shocks, especially for Italy and the Netherlands. This complements the findings from the VAR results, which showed that the TLEG hypothesis stands for both countries. The reverse holds true primarily in the cases of Austria and Greece. For the remaining countries the net spillovers are relatively small.

Given that these results reveal some useful information, they are based, so far, on single fixed parameters (i.e. a static environment). We should thus not lose sight of the fact that during the sample period, the global economy witnessed some major changes (for example, the Great Recession of 2007 and the on-going Eurozone debt crisis). Thus, it is unlikely that the values presented in Table 4 hold for the whole period of concern, and hence, it is necessary to examine how these spillovers evolve over time.

In fact, to motivate the rolling window spillovers analysis below, we have tested for structural breaks in the VAR equations for each country, based on the approach developed by Bai et al. (1998). According to this approach, the maximum Wald statistic and the logarithm of the Andrews-Ploberger exponential Wald statistic are used to test the null hypothesis of no common break in the variables (in our case, tourism and economic growth) in the VAR. The results of this analysis for each country are presented in Table 6.

\section{[Insert Table 6 around here]}

According to the results of Table 6, both test statistics reject the null hypothesis of no common break in the bivariate-VAR between tourism and economic growth in the case of Austria, Cyprus, Greece, Italy, Portugal and Spain. Conversely, the null hypothesis of no common break in the tourism-economic growth VAR in the case of Germany and the Netherlands cannot be rejected. Put differently, only in the Southern European countries, with the addition of Austria, there is evidence of a structural break in the tourismeconomic growth relationship, and which occurs during the Great Recession. Thus our 
analysis of potentially important secular and cyclical movements in spillovers between tourism and economic growth seems warranted. ${ }^{5}$

Hence, we now proceed with the presentation of the results concerning the total, directional and net spillovers between tourism and economic growth based on rollingwindow analysis.

\subsection{Spillover plots}

Figure 4 presents the 60 -month rolling-sample total spillover indices for all countries and Table 5 summarises the main descriptive statistics of these indices. ${ }^{6}$

[Insert Figure 4 around here]

[Insert Table 5 around here]

As it is demonstrated in Figure 4 and Table 5, the total spillovers indices fluctuate significantly in almost all countries. The greater fluctuations are observed in the cases of Portugal (between 7\% and 27\%), Germany (between 2\% and 26\%) and Spain (between $2 \%$ and 18\%). Likewise, there are large fluctuations in Italy (between 5\% and 22\%), Greece (between 1\% and 18\%) and Austria (between 3\% and 18\%). Conversely, the lower fluctuations belong to Cyprus (between 3\% and 13\%) and the Netherlands (between 2\% and $14 \%)$.

Furthermore, the time-varying total spillover indices illuminate that there are periods in which the tourism and economic growth interdependencies tend to be more pronounced, and periods wherein spillovers between tourism and economic growth peak. The latter seem to coincide with Euro Area and US recession periods. This is the first indication that the magnitude of the tourism-economic growth relationship is not stable over time (in the countries under examination), but rather time- and economic-event- dependent. More interesting in this respect is that nearly all countries exhibit episodes of either important increases or considerable decreases of the total spillover index. Such observation exposes the existence of two separate clusters.

The first cluster comprises Austria, Cyprus and Greece, which experience a sudden decrease in their total spillover index between 2006 and 2007. The second cluster consists of Italy, the Netherlands, Portugal and Spain, where a significant increase in interdependencies between tourism and economic growth is observed during 2007 and 2008. This is evidence of a structural break in the tourism-economic growth link during and after the

\footnotetext{
${ }^{5}$ Despite the existence of no common break in Germany and the Netherlands, we have also performed the rolling-window analysis for these two countries for robustness purposes.

${ }^{6}$ The motivation and justification for the use of 60 -month rolling windows is based on the following observations. According to Pesaran and Timmermann (2005), the choice of the window length should be determined by the existence of structural breaks in the series, and the length of the post-break observations. The authors show that, when the post break period is very large (e.g. 50 to 100 post-break observations), then the small sample bias is relatively small and will not be affected by the inclusion of pre-break data. This is the case in our analysis, as the post-break period is quite large (about 57 monthly observations, or around 4.5 years). Thus, we have rounded it up to a 60-month (or 5-year) rolling windows, which is still consistence with Pesaran and Timmermann (2005), as well with Yilmaz (2010). However, we have also experimented with the use of 48- and 72-month rolling windows and the results remained very similar to those obtained based on 60 -month rolling windows.
} 
financial crisis of 2007-08, although not in the same direction for all the countries of our sample. Germany is marked off from these clusters as it is the only one which presents two important peaks in 2000 and early 2003, respectively.

To encapsulate, it is established that the magnitude of the tourism-economic growth relationship dynamically varies over time and that there are several episodes of sudden increases or decreases of the total spillovers indices. These findings confirm those by (Lean and Tang, 2010), (Arslanturk et al., 2011) and (Tang and Tan, 2013), who report similar results for Malaysia and Turkey. Hence, a question that arises naturally, is whether the direction of the said relationship remains stable over time; a question that has not been largely answered by the literature yet.

To answer this question, the study expands its line of enquiry into the directional and net spillovers between tourism growth and economic growth over time. These are presented in Figures 5 and $6 .^{7}$

[Insert Figures 5 and 6 around here]

\section{Austria}

In the case of Austria, we observe in Figure 5 that, after an increasing trend of the directional spillovers from economic growth to tourism growth from 2001 to 2004, spillovers follow a declining trend, until the mid-2007. Thenceforth, a reverse behaviour is identified, reaching its peak almost at $15 \%$ level at the end of 2012 . On the contrary, the directional spillovers from tourism to the economy are relatively low throughout our sample period, with the only exception the period from mid-2005 to mid-2007, when they reached a peak of about $12.5 \%$. The directional spillovers show that the effects from economic growth to tourism growth, and vice versa, are moving almost in opposite directions. This result provides further support on our hypothesis of an unstable relationship between the two indicators. This is more easily observed in the net spillovers index plot (Figure 6), where economic growth is the main transmitter of shocks to the tourism sector (i.e. EDTG is identified), except for the time span from mid-2005 to mid-2007, when the reverse causality holds (i.e. TLEG is observed considering that the net transmitter is the tourism activity).

These results constitute a distinctive narrative which needs decoding. A closer reading of the country's wider context illuminates that Austria experienced its highest average real GDP growth rate of $3.7 \%$ during the period when tourism impacted on the national economy. Since the onset of the Great Recession, which led the Austrian economy to slow down, we notice that the main driver between tourism growth and economic growth relationship is the latter. Thus, we maintain that, for the case of Austria, the tourism-economic growth relationship is dynamic and evolves heterogeneously due to important changes in economic conditions. Put differently, when the economy is growing, the main transmitter is the tourism sector, whereas the reverse holds true when the Austrian (global) economy slows down or even experiences a decline, as in 2009 (-3.8\% real GDP growth rate).

\footnotetext{
${ }^{7}$ The directional spillovers show the effect of one variable's shock to the other, whereas the net spillovers document which variable is the main transmitter/receiver of these shocks. It needs to be highlighted that a net spillover around zero does not necessarily suggest no spillover effects between tourism and economic growth; it could be due to equal magnitude of spillovers between the two series.
} 


\section{Cyprus}

As with Austria, in Cyprus we observe a similar pattern of directional spillovers behaviour from economic growth to tourism growth and the reverse (Figure 5). Specifically, the economic growth spillovers to tourism growth are low until 2009, while the reverse spillovers are moderate throughout the same period, suggesting a TLEG. From 2010 onwards, we notice a continuous rise of the economic growth spillovers and a decrease of tourism growth spillovers. This is also evident in the net spillovers figure, where, since 2009, the main transmitter between tourism growth and economic growth relationship is the latter (Figure 6).

Once again we find evidence in favour of an unstable relationship, which alters its nature in the post-2009 period. A plausible explanation for this change might lie in the broader European conditions that emerged at that time and particularly, in the beginning of the Eurozone debt crisis. Greece's request for financial aid from the EU and the IMF had resonances for Cyprus, as the two economies are closely interconnected in terms of financial transactions and trade. Since that time the Cypriot economy began to show turbulence in its economic growth with low or even negative real GDP growth rates, resulting eventually to the slowdown of its tourism sector.

Another possible reason of the transformation of the tourism-economic growth relationship in Cyprus, is the fact that, the country pursued to expand its banking operations over the years and especially after joining the EMU, in 2008. From 2009 onwards, the main contributor to the Cypriot economy was indeed, the banking sector rather than the tourism sector, which was hitherto the traditional service industry that dominated the Cypriot economy.

\section{Germany}

In the case of Germany, the results reveal that the directional spillovers from both the economic growth and tourism growth are exhibiting a steady decline over the sample period apart from some notable exemptions (Figure 5). In particular, in the end of 2002, we observe a peak of $22 \%$ in the directional spillovers, which originate from tourism growth. Furthermore, two peaks in the directional spillovers from economic growth occur at the end of 2005 and 2008. The net spillovers also suggest that the tourism-economic growth relationship changes over time. To be more precise, Figure 6 shows that in the first part of our study period (i.e. until 2005), as well as, during the Great Recession, the main transmitter of the shocks is the growth of the tourism industry. The reverse holds true for the remaining periods. Yet, in post-2009, the net spillovers fluctuate almost to zero.

Overall, the evidence from both the directional and net spillovers suggests that there is a weak and bidirectional relationship between tourism growth and economic growth, especially in the post-2009 period. To some extent, this is a reasonable finding, considering two facts. First, that Germany is the leading economy of Europe and the second exporter on a global scale, specialising in non-tourism related sectors, such as automobiles, machinery, electrical equipment and chemicals. Thus, it is almost inevitable that within this framework, its tourism activity would play a less central role to the country's finances. Second, a closer look to the German tourism sector reveals that the volume of visits from 
abroad is low compared to the number of international departures (OECD, 2012). This means that there is actually a significant deficit to Germany's tourism account.

\section{Greece}

Greece is considered to be heavily dependent on tourism income with the tourism activity to account for about 16\% of the national GDP, representing a vital source of foreign exchange (OECD, 2012). It is thus surprising that, according to the directional spillovers, the relationship between the Greek tourism sector and the national economy is not very strong until 2006 (see Figure 5). This contradicts the findings from previous studies which suggest a strong link between the two variables (Dritsakis, 2012; Eeckels et al., 2012). Between 2006 and 2008 we observe that tourism growth has an increasing effect towards economic growth, while the exact reverse behaviour is observed for economic growth to tourism growth. After 2009, the picture is changing as the economic growth spillovers exhibit a rising pattern, whereas the reverse holds true for tourism growth spillovers.

In addition, the net spillovers verify that before 2006, the link between tourism and economic growth is relatively weak (Figure 6). Post 2006, though, and for a period of about three years, the tourism growth is a net transmitter, suggesting a TLEG for the case of Greece. However, after 2009 this relationship changes again in favour of the EDTG. The latter finding can be attributed to the important effects of the Greek debt crisis on the tourism-economic growth relationship. The European slowdown has seriously affected the economy of Greece, plunging it into a sharp downturn. It is indicative that the annual growth rate of the national GDP remains negative since 2008, reaching -7.1\% in 2011 (BoG, 2012). Thus, it is maintained that the economic downturn in Greece has a direct impact on the growth of the tourism industry.

\section{Italy}

In Italy we observe that overall the extent of directional spillovers from tourism growth are larger compared to the those from economic growth (Figure 5). Nevertheless, the directional spillovers suggest that both variables tend to influence each other.

In addition, although the EDTG is evident in the pre-2002 period, in the post-2002 period the net spillovers paint a very clear picture in favour of the TLEG (Figure 6). This is expected as Italy is among the most popular tourism destinations, ranking 5 th in both tourist arrivals and tourism receipts internationally (UNWTO, 2012b). It should be also added here that, although the TLEG hypothesis seems to hold in the post-2002 period, the magnitude of the tourism growth effect on economic growth fluctuates significantly. Hence, it is maintained that, even in the case of Italy, there is a time-varying shift in the behaviour between the two series.

\section{Netherlands}

The directional spillovers for Netherlands reveal that the relationship between tourism and the economy is of equal magnitude and not very strong, as on average these spillovers move closely together and account for about 4\%, respectively (Figure 5). Furthermore, the net spillovers provide a mixed picture of the interaction between the two factors (Figure

6). In particular, there are some periods during which the main transmitter of shocks 
is flowing from tourism and other, when it flows from the economy. Even though the magnitude of both the directional and net spillovers is relatively small, it is apparent that the tourism-economic growth relationship is of a bidirectional nature and does not have a stable character.

\section{Portugal}

The examination of Portugal reveals that the causality between tourism growth and the economic exhibits a clear break in the post-2008 period. More specifically, from 2005 to 2008 the tourism growth spillovers are quite large, accounting for approximately $12 \%$ (Figure 5). During the same period, economic growth spillovers are only 5\%. Nonetheless, this situation reverses in the wake of the Great Recession. Thus, overall, based on the net spillovers (Figure 6), we observe that the TLEG relationship in the pre-2008 period is transformed into an EDTG relationship in the post-2008 period.

As it is shown earlier, a similar behaviour is also noticed in the case of Cyprus and Greece, and it is suggestive of the impact of the major economic difficulties on these countries in the period after the financial crisis of 2007-08 and especially, with the onset of the Eurozone debt crisis, which has been transmitted to their tourism sectors.

\section{Spain}

The results of Spain suggest that neither tourism growth nor economic growth has a significant effect on economic growth and tourism growth, respectively, prior to 2008, given that the directional spillovers from tourism to the economy accounted for merely $3-4 \%$ (Figure 5). However, after 2008 there is a considerable increase in the magnitude of the tourism growth spillovers, which reaches a peak of almost $13 \%$. The net spillovers provide a clearer picture of the change in the tourism-economic growth relationship in the post-2008 period in favour of the TLEG (6). This finding can be explained by the fact that Spain enjoys huge success as one of the top destinations worldwide, coming fourth in international tourist arrivals and second in global tourism receipts (UNWTO, 2012b). Tourism activities represent about $10 \%$ of the country's GDP, and contribute significantly to compensating for the trade deficit (OECD, 2012).

Once again, though, we notice that the financial crisis of 2007-08 has a profound impact on the tourism-economic growth link, although in the Spanish case, the results are in contrast to those in Cyprus, Greece and Portugal. Still, this finding provides further support of the unstable and time-dependent relationship between economic growth and tourism growth.

\subsection{The Tourism-Economic growth link in the post-Great Re- cession era}

The tourism industry is vulnerable to both external and internal factors, which implies that it is easily influenced by crisis incidents (Pforr and Hosie, 2009). The severe economic downturn and its subsequent climate of uncertainty tend to have a negative domino effect on tourism activities (Henderson, 2007; Papatheodorou and Xiao, 2010; Smeral, 2009). Austerity measures, such as those implemented in Cyprus, Greece, Ireland, Italy, Portugal 
and Spain, translate into lower investments, disposable incomes and thus, reduced tourism demand and spending. In fact, there is evidence that the recent crisis did not merely result in lower visitor numbers but also in declined expenditure per visitor (Pizam, 2009). In parallel with this, the negative political scenery that prevails among certain European host countries is very likely to lead to negative tourist perceptions which in turn, can undermine demand and further decrease the number of arrivals at destinations (Pforr and Hosie, 2009).

After 2011, the global tourism market began to return to its pre-crisis growth levels (Blanke and Chiesa, 2012; UNWTO, 2012b). However, most European peripheral countries that continued to suffer from debt problems and political turmoil did not stop to report a poorer tourism performance. A case in point is Greece, which, between 2007 and 2010, saw a decline in arrivals from all its leading origin markets (indicatively, arrivals from the UK decreased by $31.2 \%$, from Italy by $27.1 \%$ and from Germany by $10 \%$, OECD, 2012). Furthermore, the Greek tourism witnessed a drop of $5.5 \%$ in 2012 whereas its turnover index in the first quarter of 2013 was $16.9 \%$ lower than that of the previous year, according to the Hellenic Statistical Authority. Pressure on tourism product prices (e.g. VAT on food and drink increased by $10 \%$ in 2011) coupled with political instability (e.g. two national elections in May and June 2012, lack of confidence regarding Greece's stay in Euro) may have indeed discouraged visitation decisions.

Another country that was proved particularly susceptible to European macroeconomic tensions is Cyprus. Although in recent years, tourism growth was overtaken by the rapid expansion of the Cypriot banking sector, the industry remained highly important for the economy. Yet, the island is suffering an on-going fall in tourist arrivals and spending that was further intensified by the crisis (OECD, 2012). The latter exerts a negative influence in dual ways first by altering the travelling behaviour of the main origin markets of Cyprus (primarily the UK) and second, by raising the price of the tourism product, which in turn weakens its competitiveness compared to similar destinations such as Turkey, Spain and Portugal (Boukas and Ziakas, 2013).

Portugal is also an interesting case, as one of the most deeply affected Eurozone countries with severe domestic economic problems. In the post-crisis era, the causality between the well-performed tourism sector and the poor-state economy of Portugal is EDTG. An examination of the tourism-related figures of the country reveals that although the Portuguese tourism performs better than those of Greece or Cyprus after the crisis, still, tourism expansion seems much constrained from 2008 onwards (OECD, 2012). To put it simply, even in the case of Portugal, it is clearly observed that the economic climate decelerated the positive growth rate that Portugal's tourism enjoyed until 2007.

On the other hand, Spain reported some growing numbers in international tourist arrivals and receipts throughout 2010-2012, despite being a crisis-stricken area (OECD, 2012). These results do not suggest immunity of the Spanish tourism product to the economic recession, but rather relate to the specific circumstances inside and outside the destination. This means that the reversal of a falling trend between 2008 and 2009 to a positive one after 2010 is not so much attributable to internal changes but rather to external events, including the outbreak of political conflicts in North Africa, i.e. the main competitor of Spain (Perles Ribes et al., 2012; Ritchie et al., 2010). Hence, Spain's fate is better than that of Greece and Cyprus, first, because it has a cheaper product that remains 
appealing to cost-conscious tourists and second, because its main competitors suffer from anomalous political circumstances. Overall, what these examples demonstrate is that the specific context of each sample country exposes multiple facets and parameters that may affect their tourism-economic growth relationship over time.

\section{Conclusion}

This paper examines the time-varying relationship between tourism growth and economic growth. To achieve that, the spillover index by Diebold and Yilmaz (2012) is employed, which generalises the original index, initially developed by Diebold and Yilmaz (2009). The study focuses on the European region and in particular, on ten EU member-countries for the period 1995 to 2012.

The findings of this study reveal the following empirical regularities. First, the tourismeconomic growth relationship is not stable over time in terms of magnitude. Such findings are in line with those by Lean and Tang (2010), Arslanturk et al. (2011) and Tang and Tan (2013), for Malaysia and Turkey. More crucially, though, we provide novel evidence that, not only the magnitude but also the direction of this economic growth and tourism growth relationship changes over time. The latter suggests that the same country can experience tourism-led economic growth or economic-driven tourism growth at different time periods. In addition, we show that the aforementioned relationship tends to exhibit changes during major economic events, such as the Great Recession of 2007 and the Eurozone debt crisis of 2010. Finally, results indicate that the impact of these economic events on the relationship between the tourism sector and the economy is more pronounced to Cyprus, Greece, Portugal and Spain, which are the European countries that have witnessed the greatest economic downturn since 2009.

These results are particularly significant for policy makers, suggesting that the strategic planning of the tourism sector expansion, when aimed at stimulating the national economy, and vice versa, should take into consideration this time-varying relationship. Thus, policy making should be flexible and thus responsive to the changing character of the tourism-economic growth relationship rather than exhibiting inertia. This is due to the fact that a TLEG condition demands the adaption of a different set of strategies compared to an EDTG environment.

For example, during crisis periods, we observe that for most countries the tourismeconomic growth relationship changes from TLEG to EDTG. This is suggestive of the fact that when countries try to decrease their fiscal deficits and close budget gaps, they end up hampering tourism activity (e.g. due to limited funding, infrastructure, etc). Therefore, at these particular times the national development strategies should try to alleviate the negative effects of the economic conditions on the tourism sector by employing costeffective strategies. Such strategies could promote tourism activity and increase tourism income and they may lead to a change of the current EDTG to TLEG, paving the way to the improvement of the economic conditions.

More specifically, countries such as Cyprus, Greece or Portugal could engage in more targeted marketing and in promoting alternative tourism packages (such as culturalheritage tourism, wine and gastronomy tourism, agrotourism, conference tourism and religious tourism) to complement the existing sea, sun and sand experiences. Given that 
these countries have already the resources to accommodate these tourism segments, such promoting activities will achieve two aims. First, they will minimise seasonality of tourism visits and second, they will attract visitors with higher propensity to spend. For instance, cultural-heritage tourists are characterised by their high-spending capacity and low price elasticity (Aguiló et al., 2005; OECD, 2009; Khovanova-Rubicondo, 2011). At the same time, they could improve the distribution of tourism information by using web and mobile technologies, which will encourage a two-way communication and will allow the live sharing of information and feedback. Such initiatives will increase tourist satisfaction and thus improve tourism numbers. Furthermore, given the popularity of these destinations due to their natural and built environment, these countries could focus on vocational training and attract a high number of apprenticeships, even from abroad. This will enhance the quality of service, while at the same time apprentices could act as "ambassadors" of the destinations' offer.

On the other hand, countries such as Italy or Spain, which were TLEG during the economic recession, should target at the sustainability of their tourism industry and use tourism as a means to promote regional development by (re)distributing tourism benefits across the economy. In addition, these countries should provide incentives to tourism businesses for reinvestments of profits.

It should be also underlined that all countries should regulate further their tourism industries and proceed to systematic inspections in an effort to alleviate incidents of tourist exploitation, over-pricing, insecurity or fraud.

Finally, these novel findings are significant for researchers, as they show that this strand of the literature deserves more of their attention. In this paper, we provide some interesting ideas for further research. Although it is beyond our scope, future work could further investigate the tourism-economic growth relationship using a variety of other timevarying measures such as multivariate GARCH models (the DCC and BEKK of Engle, 2002; Engle and Kroner, 1995, , respectively) and the CoVaR measure of Adrian and Brunnermeier (2008). Another avenue for future research is the examination of the determinants of the time-varying relationship between the tourism sector and the economy, as well as, the development of a theoretically coherent framework explaining the tourismeconomic growth nexus.

\section{Acknowledgements}

The authors like to thank Stephen George Hall (Editor) and three anonymous reviewers for helpful comments on a previous version of this paper. The usual disclaimer applies.

\section{References}

Adrian, T., Brunnermeier, M. K., 2008. CoVaR. Staff Reports 348, Federal Reserve Bank of New York.

Aguiló, E., Alegre, J., Sard, M., 2005. The persistence of the sun and sand tourism model. Tourism Management 26 (2), $219-231$. 
Andereck, K. L., Valentine, K. M., Knopf, R. C., Vogt, C. A., 2005. Residents' perceptions of community tourism impacts. Annals of Tourism Research 32 (4), 1056-1076.

Andriotis, K., 2002. Scale of hospitality firms and local economic development-evidence from Crete. Tourism Management 23 (4), 333-341.

Antonakakis, N., 2012. Exchange return co-movements and volatility spillovers before and after the introduction of euro. Journal of International Financial Markets, Institutions and Money 22 (5), 1091-1109.

Antonakakis, N., Badinger, H., 2014. International business cycle spillovers since the 1870s. Applied Economics 46 (30), 3682-3694.

Apergis, N., Payne, J. E., 2012. Research note: Tourism and growth in the Caribbean evidence from a panel error correction model. Tourism Economics 18 (2), 449-456.

Arslanturk, Y., Balcilar, M., Ozdemir, Z. A., 2011. Time-varying linkages between tourism receipts and economic growth in a small open economy. Economic Modelling 28 (1), 664-671.

Bai, J., Lumsdaine, R. L., Stock, J. H., 1998. Testing for and Dating Common Breaks in Multivariate Time Series. Review of Economic Studies 65 (3), 395-432.

Balaguer, J., Cantavella-Jorda, M., 2002. Tourism as a long-run economic growth factor: The Spanish case. Applied Economics 34 (7), 877-884.

Bjørnland, H. C., Leitemo, K., 2009. Identifying the interdependence between US monetary policy and the stock market. Journal of Monetary Economics 56 (2), 275-282.

Blanke, J., Chiesa, T., 2012. The travel and tourism competitiveness report 2011: Beyond the downturn. World Economic Forum (WEO).

BoG, 2012. The Bank of Greece interim report on monetary policy 2012. The Bank of Greece.

Boukas, N., Ziakas, V., 2013. Impacts of the global economic crisis on Cyprus tourism and policy responses. International Journal of Tourism Research 15 (4), 329-345.

Brida, J., Pulina, M., 2010. A literature review on the tourism-led-growth hypothesis. Working Paper CRENoS 201017, Centre for North South Economic Research, University of Cagliari and Sassari, Sardinia.

Bubák, V., Kocenda, E., Zikes, F., 2011. Volatility transmission in emerging European foreign exchange markets. Journal of Banking \& Finance 35 (11), 2829-2841.

Chatziantoniou, I., Filis, G., Eeckels, B., Apostolakis, A., 2013. Oil prices, tourism income and economic growth: A structural \{VAR $\}$ approach for European Mediterranean countries. Tourism Management 36 (0), 331-341.

Chen, C.-F., Chiou-Wei, S. Z., 2009. Tourism expansion, tourism uncertainty and economic growth: New evidence from taiwan and korea. Tourism Management 30 (6), 812-818.

Croes, R., Vanegas, M., 2008. Cointegration and Causality between Tourism and Poverty Reduction. Journal of Travel Research 47 (1), 94-103.

Croes, R. R., 2006. A paradigm shift to a new strategy for small island economies: Embracing demand side economics for value enhancement and long term economic stability. Tourism Management 27 (3), 453-465.

Dickey, D. A., Fuller, W. A., 1979. Distribution of the Estimators for Autoregressive Time Series With a Unit Root. Journal of the American Statistical Association 74 (366), 427431. 
Diebold, F., Yilmaz, K., 2009. Measuring financial asset return and volatility spillovers, with application to global equity markets. Economic Journal 119 (534), 158-171.

Diebold, F. X., Yilmaz, K., 2012. Better to give than to receive: Predictive directional measurement of volatility spillovers. International Journal of Forecasting 28 (1), 57-66.

Dolado, J. J., Lutkepohl, H., 1996. Making wald tests work for cointegrated VAR systems. Econometric Reviews 15 (4), 369-386.

Dritsakis, N., 2012. Tourism development and economic growth in seven mediterranean countries: A panel data approach. Tourism Economics 18 (4), 801-816.

Durbarry, R., 2004. Tourism and economic growth: the case of mauritius. Tourism Economics 10 (4), 389-401.

Eeckels, B., Filis, G., Leon, C., 2012. Tourism income and economic growth in greece: Empirical evidence from their cyclical components. Tourism Economics 18 (4), 817-834.

Elliott, G., Rothenberg, T. J., Stock, J. H., 1996. Efficient Tests for an Autoregressive Unit Root. Econometrica 64 (4), 813-836.

Engle, R., 2002. Dynamic Conditional Correlation: A simple class of multivariate Generalized Autoregressive Conditional Heteroskedasticity Models. Journal of Business 86 Economic Statistics 20 (3), 339-350.

Engle, R. F., Kroner, K. F., 1995. Multivariate simultaneous generalized ARCH. Economic Theory 11, 122-150.

Espinoza, R., Fornari, F., Lombardi, M. J., 2012. The role of financial variables in predicting economic activity. Journal of Forecasting 31 (1), 15-46.

Fayissa, B., Nsiah, C., Tadesse, B., 2011. Research note: Tourism and economic growth in Latin American countries further empirical evidence. Annals of Tourism Research 17 (6), 1365-1373.

Henderson, J. C., 2007. Tourism Crises: Causes, Consequences $\&$ Management. London: Elsevier.

Ivanov, S., Webster, C., 2013. Tourism's impact on growth: The role of globalisation. Annals of Tourism Research 41, 231-236.

Katircioglu, S. T., 2009. Revisiting the tourism-led-growth hypothesis for Turkey using the bounds test and johansen approach for cointegration. Tourism Management 30 (1), $17-20$.

Khovanova-Rubicondo, K., 2011. Impact of European cultural routes on SMEs' innovation, competitiveness, and clustering. Strasbourg: Council of Europe Publishing.

Koop, G., Pesaran, M. H., Potter, S. M., 1996. Impulse response analysis in nonlinear multivariate models. Journal of Econometrics 74 (1), 119-147.

Krueger, A. O., 1980. Trade policy as an input to development. American Economic Review 70 (2), 288-292.

Lanza, A., Pigliaru, F., 2000. Why are tourism countries small and fast-growing? In: Amedeo Fossati, and Giorgio Panella (ed.), Tourism and Sustainable Economic Development. Kluwer Academic Publishers, Dordrecht, pp. 57-69.

Laopodis, N. T., 2009. Are fundamentals still relevant for European economies in the post-Euro period? Economic Modelling 26 (5), 835-850.

Lean, H. H., Tang, C. F., 2010. Is the tourism-led growth hypothesis stable for Malaysia? A note. International Journal of Tourism Research 12 (4), 375-378.

Lee, C.-C., Chang, C.-P., 2008. Tourism development and economic growth: A closer look 
at panels. Tourism Management 29 (1), 180-192.

Lee, J., Strazicich, M. C., 2003. Minimum Lagrange Multiplier Unit Root Test with Two Structural Breaks. The Review of Economics and Statistics 85 (4), 1082-1089.

Lee, J. W., Brahmasrene, T., 2013. Investigating the influence of tourism on economic growth and carbon emissions: Evidence from panel analysis of the European Union. Tourism Management 38, 69-76.

Lutkepohl, H., 2006. New introduction to multiple time series analysis. Berlin: SpringerVerlag.

Matarrita-Cascante, D., 2010. Beyond Growth: Reaching tourism-led development. Annals of Tourism Research 37 (4), 1141-1163.

McKinnon, R. I., 1964. Foreign exchange constraint in economic development and efficient aid allocation. The Economic Journal 74 (294), 388-409.

McMillan, D. G., Speight, A. E., 2010. Return and volatility spillovers in three euro exchange rates. Journal of Economics and Business 62 (2), 79-93.

Narayan, P. K., 2004. Fiji's tourism demand: the ardl approach to cointegration. Tourism Economics 10 (2), 193-206.

OECD, 2009. The impact of culture on tourism. Organisation for Economic Co-operation and Development Publishing (OECD). Paris: OECD.

OECD, 2012. OECD Tourism Trends and Policies 2012. OECD Publishing.

Oh, C.-O., 2005. The contribution of tourism development to economic growth in the korean economy. Tourism Management 26 (1), 39-44.

Papatheodorou, A. Rosselló, J., Xiao, H., 2010. Global economic crisis and tourism: Consequences and perspectives. Journal of Travel Research 49 (1), 39-45.

Parrilla, J. C., Font, A. R., Nadal, J. R., 2007. Tourism and long-term growth a Spanish perspective. Annals of Tourism Research 34 (3), 709-726.

Payne, J. E., Mervar, A., 2010. Research note: The tourism-growth nexus in croatia. Tourism Economics 16 (4), 1089-1094.

Peersman, G., Van Robays, I., 2012. Cross-country differences in the effects of oil shocks. Energy Economics 34 (5), 1532-1547.

Perles Ribes, J., Ramón Rodrguez, A., Serrano, A., Izquierdo, L., 2012. Cycles, economic crisis and tourism competitiveness in Spain: Mechanisms of transmission and structural effects. SSRN 2201776.

Perron, P., Ng, S., 1996. Useful Modifications to Some Unit Root Tests with Dependent Errors and Their Local Asymptotic Properties. Review of Economic Studies 63 (3), 435-463.

Pesaran, H. H., Shin, Y., 1998. Generalized impulse response analysis in linear multivariate models. Economics Letters 58 (1), 17-29.

Pesaran, M. H., Timmermann, A., 2005. Small sample properties of forecasts from autoregressive models under structural breaks. Journal of Econometrics 129 (1-2), 183-217.

Pforr, C., Hosie, P., 2009. Crisis management in the tourism industry. Farnham: Ashgate.

Pizam, A., 2009. The global financial crisis and its impact on the hospitality industry. International Journal of Hospitality Management 28 (3), 301.

Po, W.-C., Huang, B.-N., 2008. Tourism development and economic growth - a nonlinear approach. Physica A: Statistical Mechanics and its Applications 387 (22), 5535-5542.

Pratt, S., 2011. The global nancial crisis and its impact on the hospitality industry. 
International Journal of Hospitality Management 28, 301.

Proenca, S., Soukiazis, E., 2008. Tourism as an economic growth factor: A case study for southern European countries. Tourism Economics 14 (4), 791.

Ridderstaat, J., Croes, R., Nijkamp, P., 2013. Tourism and Long-run Economic Growth in Aruba. International Journal of Tourism Research.

Ritchie, J. B., Molinar, C. M. A., Frechtling, D. C., 2010. Impacts of the world recession and economic crisis on tourism: North America. Journal of Travel Research 49 (1), $5-15$.

Schubert, S. F., Brida, J. G., Risso, W. A., 2011. The impacts of international tourism demand on economic growth of small economies dependent on tourism. Tourism Management 32 (2), 377-385.

Seetanah, B., 2011. Assessing the dynamic economic impact of tourism for island economies. Annals of Tourism Research 38 (1), 291-308.

Smeral, E., 2009. The impact of the financial and economic crisis on European tourism. Journal of Travel Research 48 (1), 3-13.

Sugiyarto, G., Blake, A., Sinclair, M., 2003. Tourism and globalization: Economic impact in Indonesia. Annals of Tourism Research 30 (3), 683-701.

Surugiu, C., Surugiu, M. R., 2013. Is the tourism sector supportive of economic growth? Empirical evidence on Romanian tourism. Tourism Economics 19 (1), 115-132.

Tang, C. F., 2011. Is the tourism-led growth hypothesis valid for Malaysia? A view from disaggregated tourism markets. International Journal of Tourism Research 13 (1), 97101.

Tang, C. F., Tan, E. C., 2013. How stable is the tourism-led growth hypothesis in Malaysia? Evidence from disaggregated tourism markets. Tourism Management 37, $52-57$.

Tang, C.-H. H., Jang, S. S., 2009. The tourism-economy causality in the United States: A sub-industry level examination. Tourism Management 30 (4), 553-558.

Toda, H. Y., Yamamoto, T., 1995. Statistical inference in vector autoregressions with possibly integrated processes. Journal of Econometrics 66 (1-2), 225-250.

UNWTO, 2012a. United Nations World Tourism Organisation: Annual report 2011. Madrid: UNWTO.

UNWTO, 2012b. UNWTO tourism highlights 2012 edition. Madrid: UNWTO.

Yilmaz, K., 2010. Return and volatility spillovers among the East Asian equity markets. Journal of Asian Economics 21 (3), 304-313.

Zhou, X., Zhang, W., Zhang, J., 2012. Volatility spillovers between the Chinese and world equity markets. Pacific-Basin Finance Journal 20 (2), 247-270. 
Table 1: Data availability

\begin{tabular}{lc}
\hline \hline Country & Period \\
AUT & 1996M1-2012M12 \\
GER & 1995M1-2012M12 \\
GRC & 1995M3-2012M12 \\
ITA & 1995M1-2012M12 \\
PRT & 2000M1-2012M12 \\
ESP & 1995M3-2012M12 \\
\hline \hline
\end{tabular}




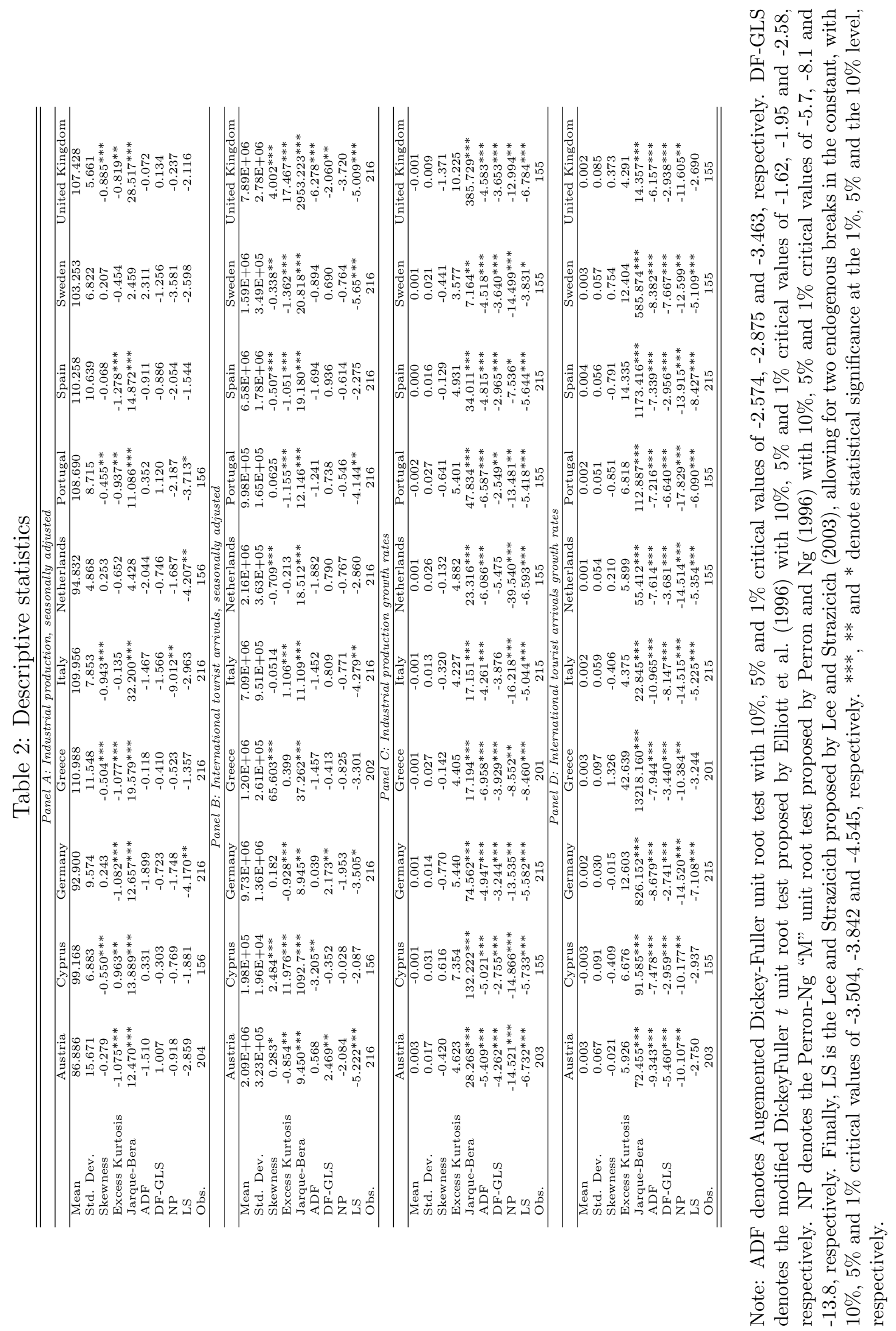


Table 3: Generic growth spillover table

\begin{tabular}{|c|c|c|c|c|}
\hline Response from: & Shock by: & $\begin{array}{l}\text { Industrial } \\
\text { Production }\end{array}$ & $\begin{array}{l}\text { Tourist } \\
\text { Arrivals }\end{array}$ & $\begin{array}{l}\text { Contribution } \\
\text { FROM others }\end{array}$ \\
\hline Industrial Production & & $\mathrm{A}$ & $\mathrm{B}$ & $\mathrm{B}$ \\
\hline Tourist Arrivals & & $\mathrm{C}$ & $\mathrm{D}$ & $\mathrm{C}$ \\
\hline Contributions TO others & & $\mathrm{C}$ & B & \\
\hline Contributions including own & & $\mathrm{A}+\mathrm{C}$ & $\mathrm{B}+\mathrm{D}$ & Total Spillover \\
\hline Net spillovers & & C-B & $\mathrm{B}-\mathrm{C}$ & Index: $(\mathrm{B}+\mathrm{C}) / 2$ \\
\hline
\end{tabular}

Note: A, B, C and D correspond to the contribution to the forecast error variance of series $i$ and $j$, stemming from innovations to series $j$ and $i$, where $i, j$ are the industrial production and international tourist arrivals growth rates. 
Table 4: Spillover table

\begin{tabular}{|c|c|c|c|c|c|c|c|}
\hline & \multicolumn{3}{|c|}{ Austria } & & \multicolumn{3}{|c|}{ Cyprus } \\
\hline & IP & TA & \multirow{6}{*}{$\begin{array}{l}\text { Total spillover } \\
\text { index: } 8.60 \%\end{array}$} & & IP & $\mathrm{TA}$ & \multirow{6}{*}{$\begin{array}{l}\text { Total spillover } \\
\text { index: } 1.55 \%\end{array}$} \\
\hline IP & 94.70 & 5.30 & & IP & 98.70 & 1.30 & \\
\hline $\mathrm{TA}$ & 11.90 & 88.10 & & $\mathrm{TA}$ & 1.80 & 98.20 & \\
\hline Contr. TO others & 11.90 & 5.30 & & Contr. TO others & 1.80 & 1.30 & \\
\hline Contr. incl. own & 106.60 & 93.40 & & Contr. incl. own & 100.50 & 99.50 & \\
\hline \multirow[t]{3}{*}{ Net spillovers } & 6.60 & -6.60 & & Net spillovers & 0.50 & -0.50 & \\
\hline & \multicolumn{3}{|c|}{ Germany } & & \multicolumn{3}{|c|}{ Greece } \\
\hline & IP & $\mathrm{TA}$ & & & IP & TA & \multirow{6}{*}{$\begin{array}{l}\text { Total spillover } \\
\text { index: } 3.30 \%\end{array}$} \\
\hline IP & 96.60 & 3.40 & \multirow{5}{*}{$\begin{array}{l}\text { Total spillover } \\
\text { index: } 2.65 \%\end{array}$} & IP & 99.90 & 0.10 & \\
\hline $\mathrm{TA}$ & 1.90 & 98.10 & & $\mathrm{TA}$ & 6.50 & 93.50 & \\
\hline Contr. TO others & 1.90 & 3.40 & & Contr. TO others & 6.50 & 0.10 & \\
\hline Contr. incl. own & 98.50 & 101.50 & & Contr. incl. own & 106.40 & 93.60 & \\
\hline \multirow[t]{3}{*}{ Net spillovers } & -1.50 & 1.50 & & Net spillovers & 6.40 & -6.40 & \\
\hline & \multicolumn{3}{|c|}{ Italy } & & \multicolumn{3}{|c|}{ Netherlands } \\
\hline & IP & $\mathrm{TA}$ & \multirow{6}{*}{$\begin{array}{l}\text { Total spillover } \\
\text { index: } 5.75 \%\end{array}$} & & IP & TA & \multirow{6}{*}{$\begin{array}{l}\text { Total spillover } \\
\text { index: } 3.25 \%\end{array}$} \\
\hline IP & 92.40 & 7.60 & & IP & 95.40 & 4.60 & \\
\hline $\mathrm{TA}$ & 3.90 & 96.10 & & $\mathrm{TA}$ & 1.90 & 98.10 & \\
\hline Contr. TO others & 3.90 & 7.60 & & Contr. TO others & 1.90 & 4.60 & \\
\hline Contr. incl. own & 96.30 & 103.70 & & Contr. incl. own & 97.30 & 102.70 & \\
\hline \multirow[t]{3}{*}{ Net spillovers } & -3.70 & 3.70 & & Net spillovers & -2.70 & 2.70 & \\
\hline & \multicolumn{3}{|c|}{ Portugal } & & \multicolumn{3}{|c|}{ Spain } \\
\hline & IP & $\mathrm{TA}$ & & & IP & TA & \\
\hline IP & 91.60 & 8.40 & & IP & 95.90 & 4.10 & \\
\hline $\mathrm{TA}$ & 7.70 & 92.30 & & $\mathrm{TA}$ & 3.40 & 96.60 & \\
\hline Contr. TO others & 7.70 & 8.40 & Total spillover & Contr. TO others & 3.40 & 4.10 & Total spillover \\
\hline Contr. incl. own & 99.30 & 100.70 & index: $8.05 \%$ & Contr. incl. own & 99.30 & 100.70 & index: $3.75 \%$ \\
\hline Net spillovers & -0.70 & 0.70 & & Net spillovers & -0.70 & 0.70 & \\
\hline
\end{tabular}

Note: IP and TA denote industrial production growth and tourist arrivals growth, respectively.

Table 5: Descriptive statistics of the time-varying total spillover indices

\begin{tabular}{lcccccccc}
\hline \hline & Austria & Cyprus & Germany & Greece & Italy & Netherlands & Portugal & Spain \\
\hline Mean & 12.183 & 7.641 & 10.481 & 9.911 & 13.733 & 6.361 & 15.729 & 8.172 \\
Maximum & 18.028 & 12.979 & 26.400 & 18.207 & 22.184 & 13.807 & 27.473 & 17.913 \\
Minimum & 3.323 & 2.809 & 2.247 & 1.419 & 5.501 & 2.087 & 6.937 & 2.124 \\
Std. Dev. & 3.092 & 2.387 & 5.301 & 3.454 & 3.971 & 2.550 & 4.488 & 4.118 \\
Observations & 139 & 94 & 148 & 139 & 149 & 94 & 94 & 153 \\
\hline \hline
\end{tabular}


Table 6: Results of common breaks in bivariate-VARs between tourism and economic growth

\begin{tabular}{lllll}
\hline \hline Country & Break & 90\% Conf. Int. & Sup- $W$ & Exp- $W$ \\
\hline Austria & 2008M04 & 2004M10-2011M10 & $6.9628^{* *}$ & $1.6848^{* *}$ \\
Cyprus & 2008M08 & 2006M12-2010M04 & $12.2404^{* * * *}$ & $3.9131^{* * *}$ \\
Germany & 2003M02 & 1995M06-2012M12 & 2.6218 & 0.2678 \\
Greece & 2009M02 & 2007M09-2010M07 & $14.5742^{* * *}$ & $4.9115^{* * *}$ \\
Italy & 2008M04 & 2004M04-2012M04 & $6.1038^{* *}$ & $1.1787^{*}$ \\
Netherlands & 2008M01 & 2000M06-2012M12 & 2.6103 & 0.2559 \\
Portugal & 2008M03 & 2003M09-2012M09 & $4.8224^{*}$ & $0.9947^{*}$ \\
Spain & 2008M03 & 2006M12-2009M06 & $18.8826^{* * *}$ & $6.3099^{* * *}$ \\
\hline \hline
\end{tabular}

Note: Sup- $W$ and Exp- $W$ are the maximum supremum Wald statistic and the logarithm of the AndrewsPloberger exponential Wald statistic, respectively. Lag lengths of the bivariate-VARs between industrial production growth and international tourist arrivals growth in each country were selected using the BIC with a minimum of one lag and a maximum of six lags. $p$-values were computed using the asymptotic distributions of the relevant statistic. We have set the trimming of the initial fraction of the sample equal to 0.15. For details, see Bai et al. (1998). 
Figure 1: Seasonally adjusted series of industrial production and international tourist arrivals

Panel A: Industrial production
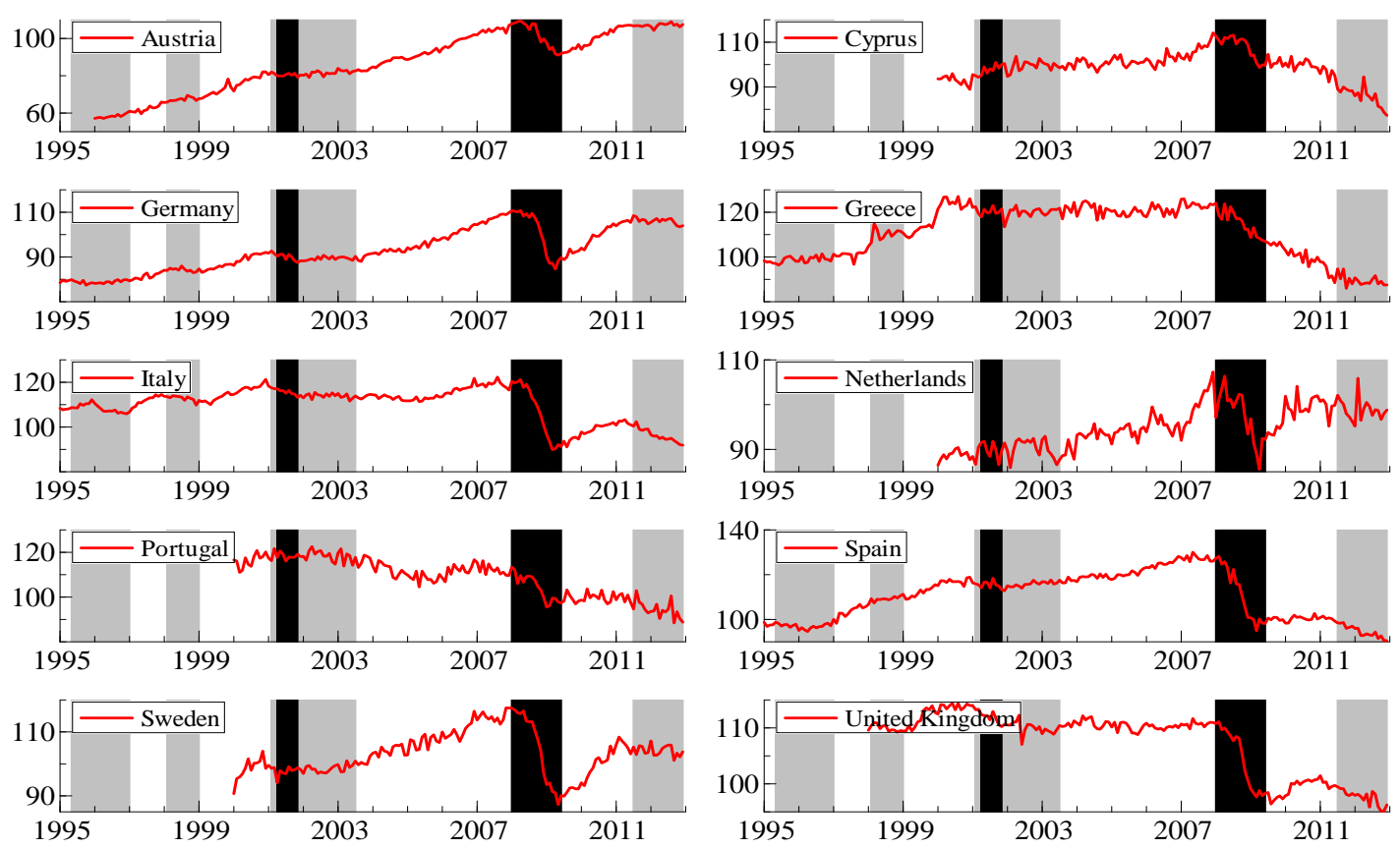

Panel B: International tourist arrivals
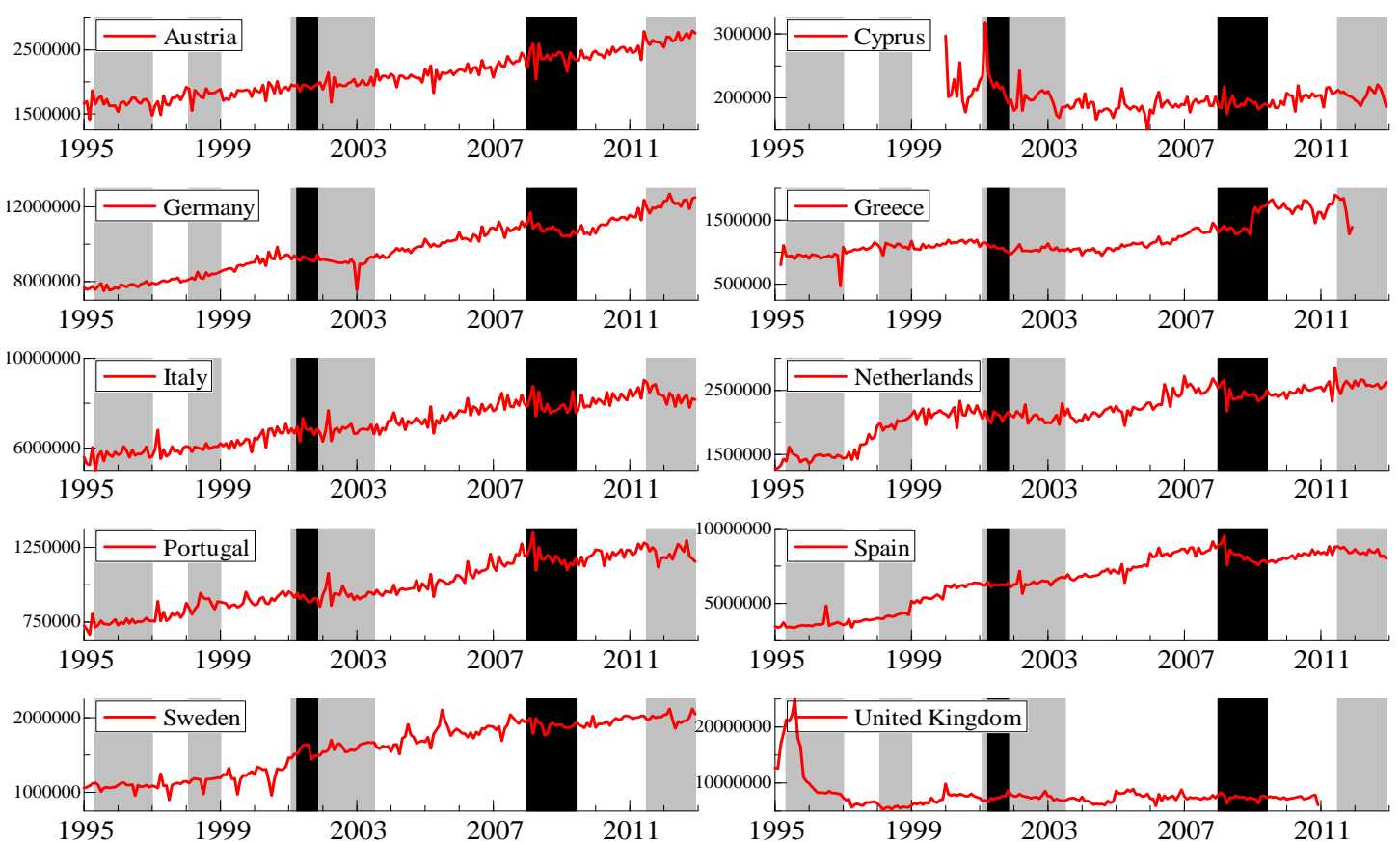

Note: Country specific time span is given in Table 1. Grey shading denotes Euro Area recessions as defined by the CEPR, while black shading denotes US recessions as defined by NBER. 
Figure 2: Growth rate of industrial production and international tourist arrivals Panel A: Industrial production
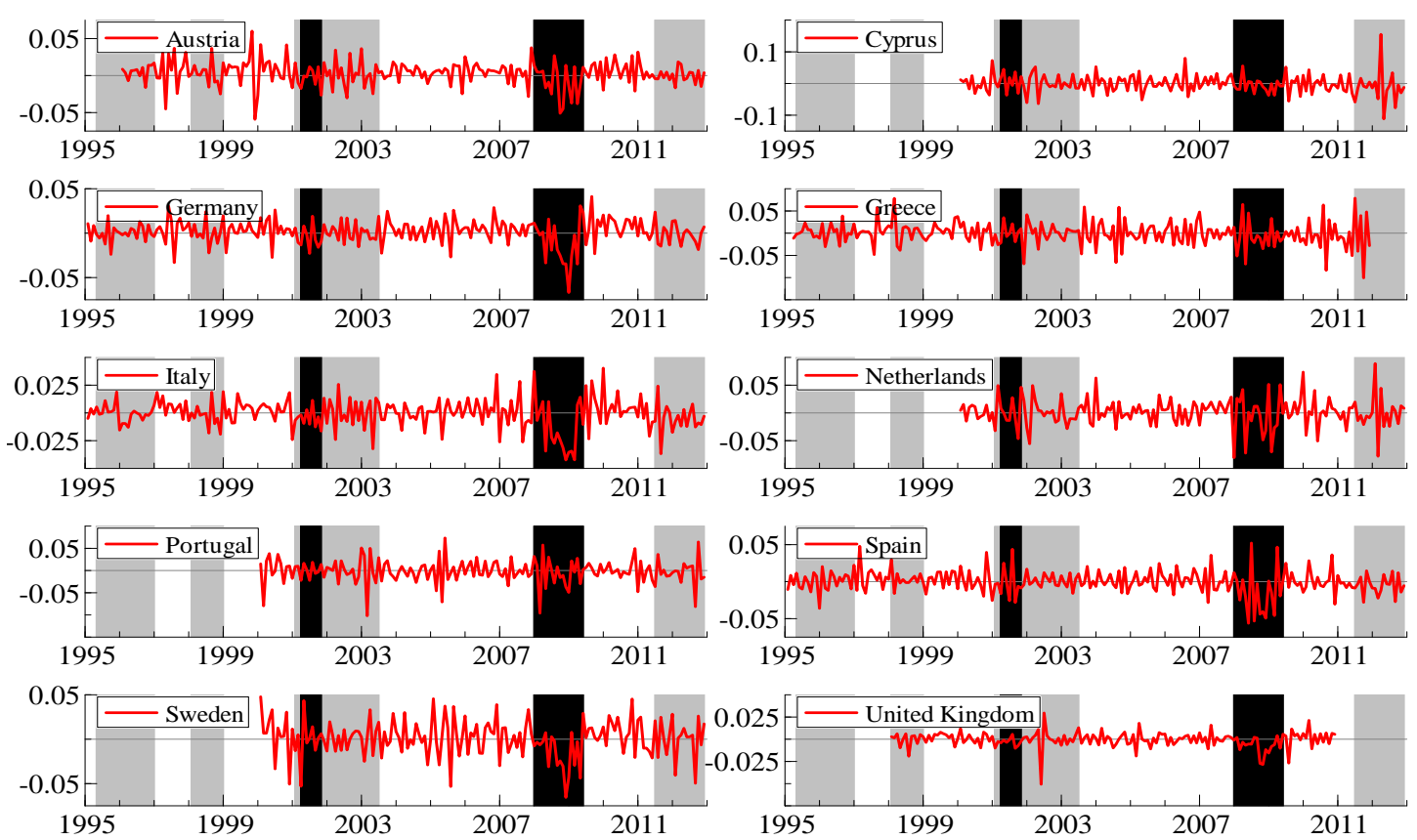

Panel B: International tourist arrivals
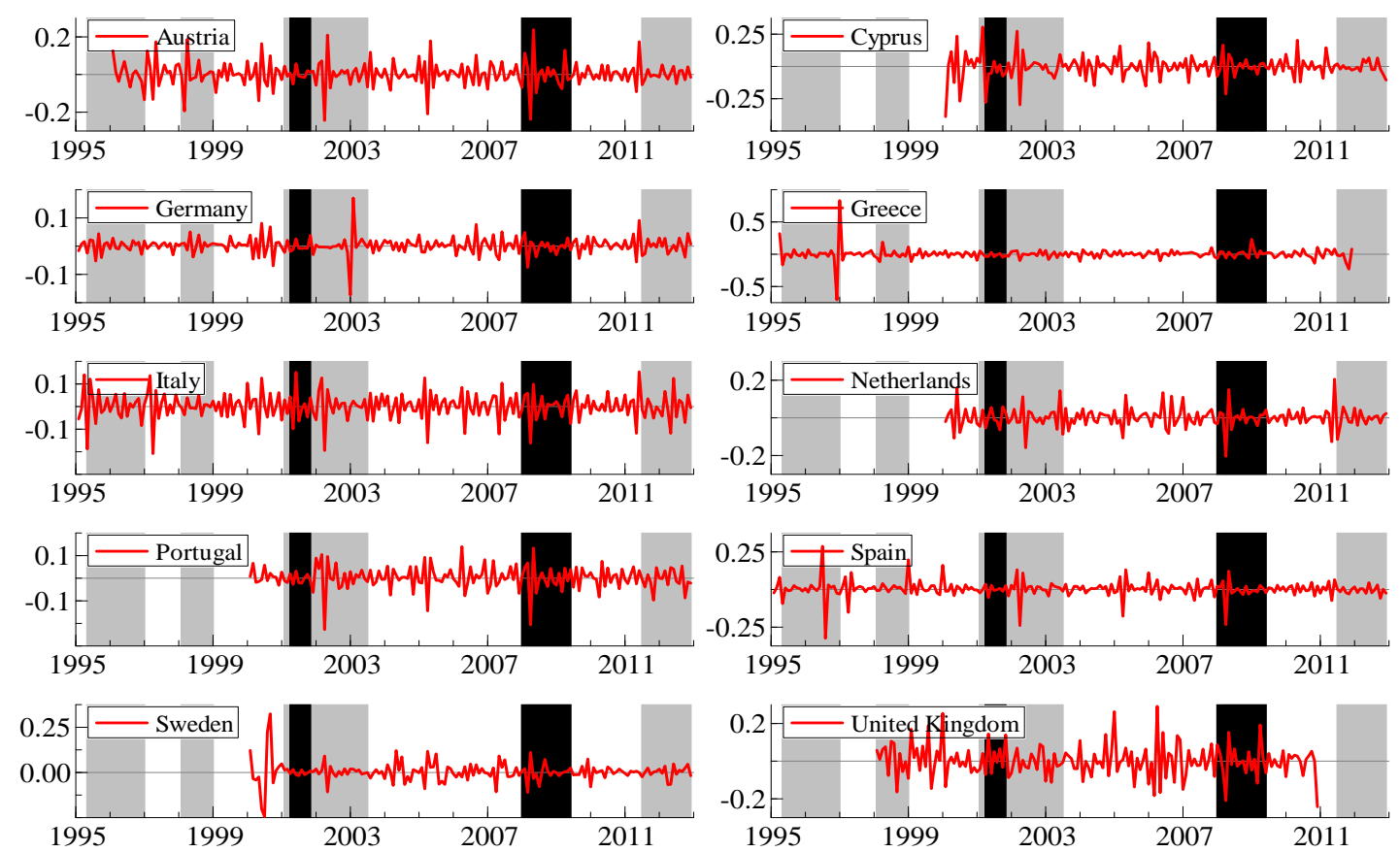

Note: Country specific time span is given in Table 1. Grey shading denotes Euro Area recessions as defined by the CEPR, while black shading denotes US recessions as defined by NBER. 
Figure 3: Granger-causality between economic growth and tourism growth

AUSTRIA

\section{CYPRUS}

GERMANY

GREECE

ITALY

NETHERLANDS

PORTUGAL

SPAIN

SWEDEN

UK
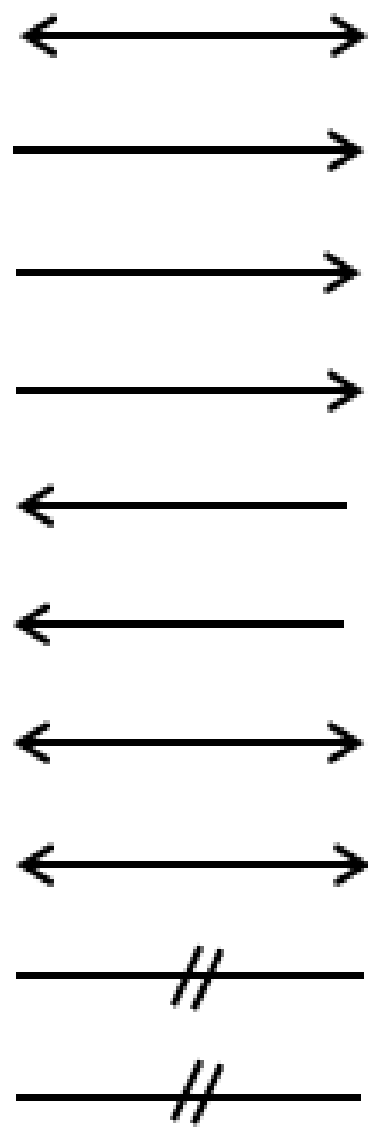
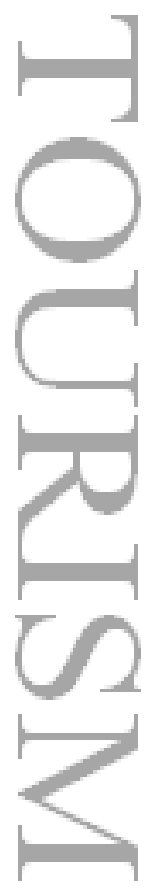
Figure 4: Total spillover index of industrial production and international tourist arrivals growth
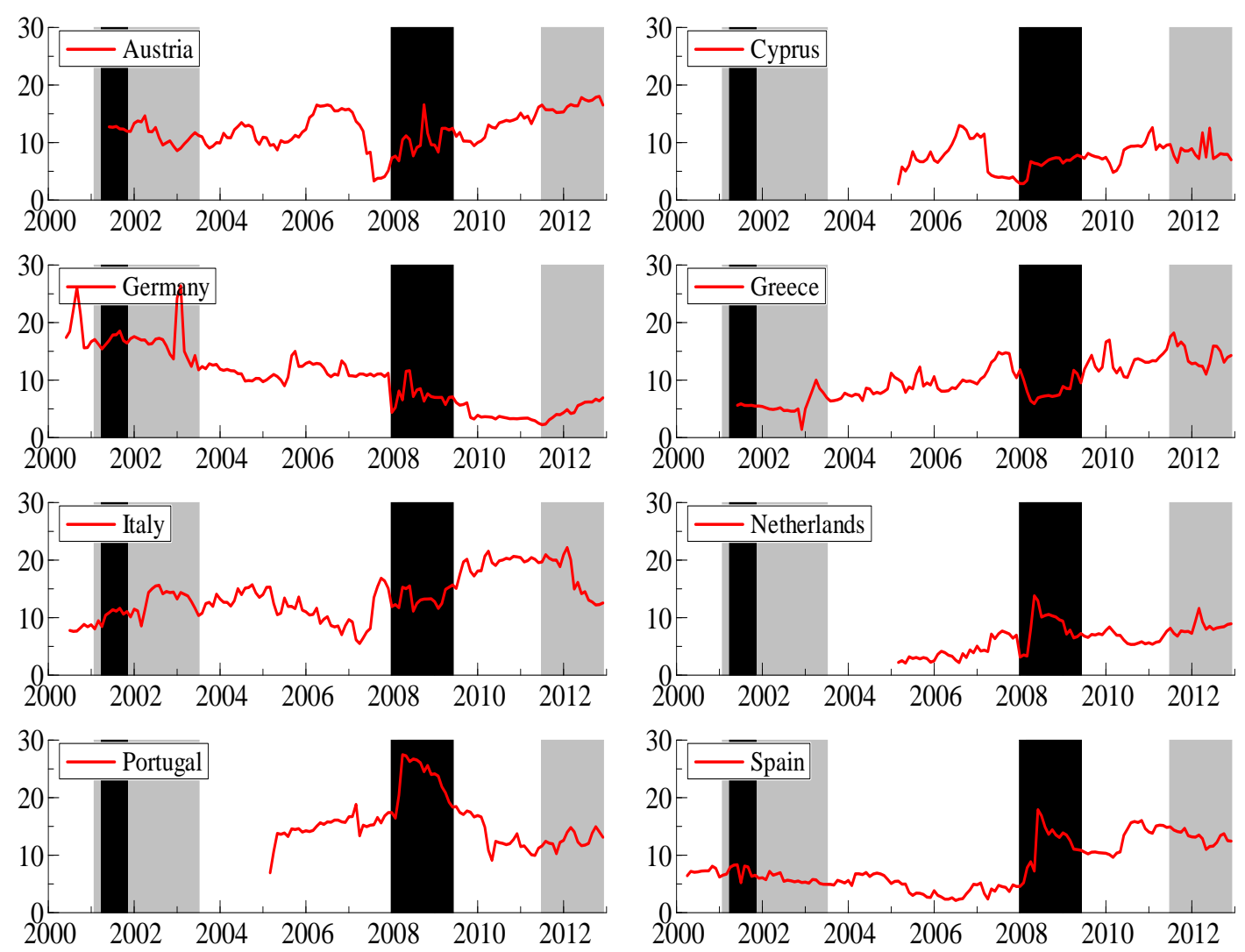

Note: Plot of moving total spillover indexes estimated using 60-month rolling windows (and hence, starting 60 months after the first available data for each country). Grey shading denotes Euro Area recessions as defined by the CEPR, while black shading denotes US recessions as defined by NBER. 
Figure 5: Directional spillovers FROM industrial production and international tourist arrivals growth
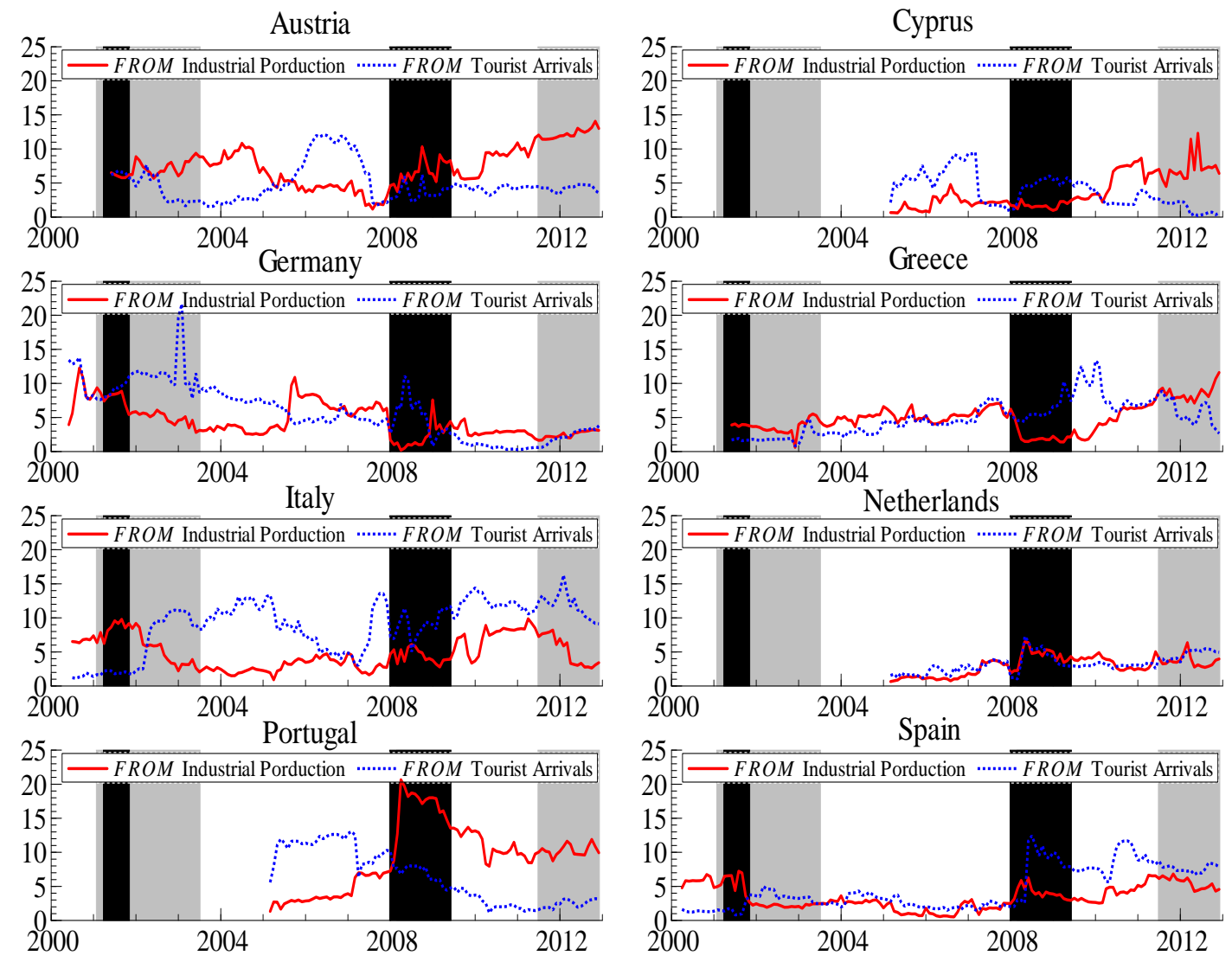

Note: Grey shading denotes Euro Area recessions as defined by the CEPR, while black shading denotes US recessions as defined by NBER. See also notes in Table 4. 
Figure 6: Net Spillovers between industrial production and international tourist arrivals growth
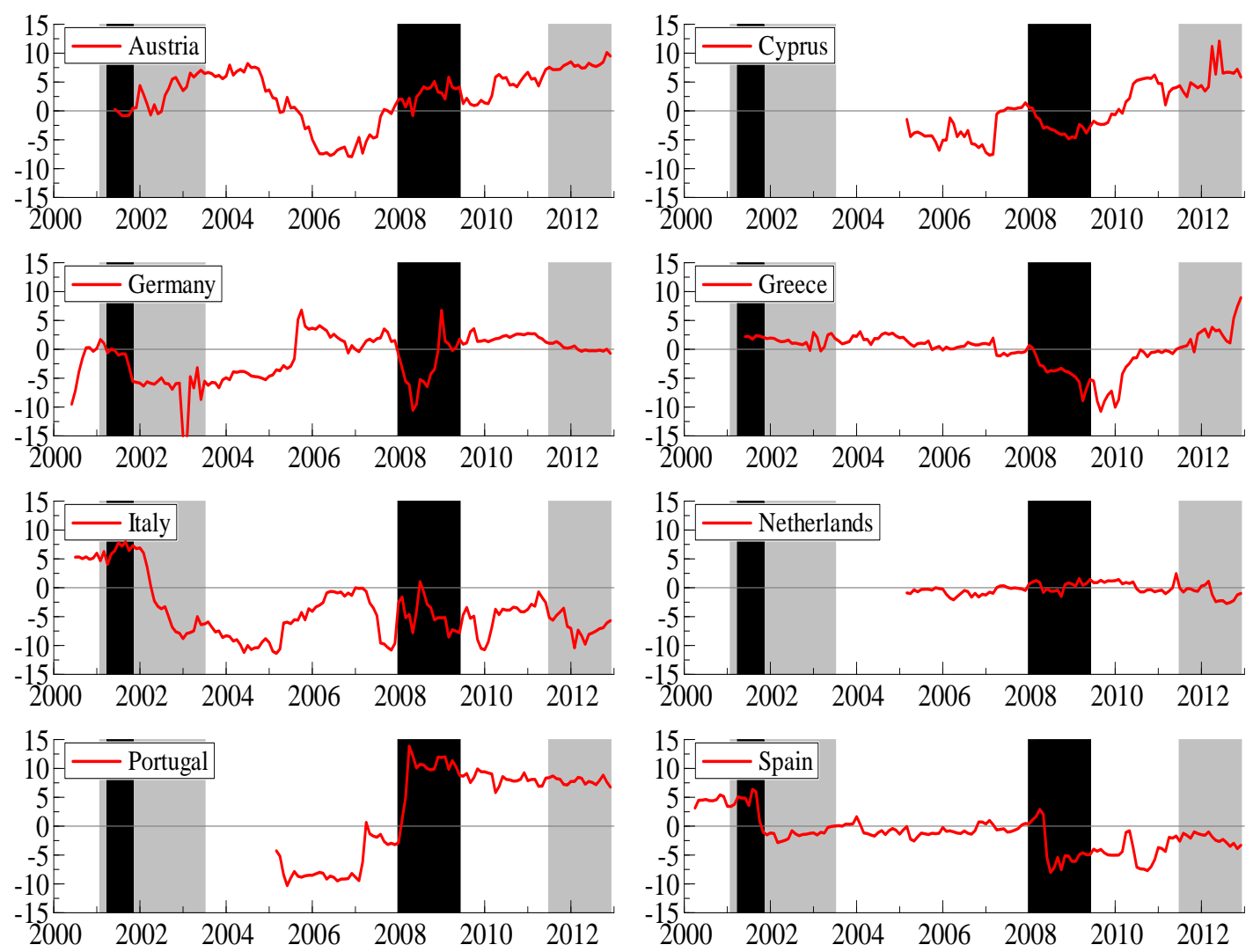

Note: Positive values indicate that industrial production (international tourist arrivals) is the net transmitter of shocks, while negative values indicate that industrial production (international tourist arrivals) is the net receiver of shocks. Grey shading denotes Euro Area recessions as defined by the CEPR, while black shading denotes US recessions as defined by NBER. See also notes in Table 4. 